\title{
IPO Research in Malaysia: A Review of Under-Pricing Phenomenon
}

\author{
Ali Albada \\ Universiti Kebangsaan Malaysia, Malaysia. \\ Othman Yong* \\ Universiti Kebangsaan Malaysia, Malaysia. \\ *Corresponding author: othmanyo@ukm.edu.my
}

\section{A R T I C L E I N F O}

Article history:

Received 8 April 2018

Revised form 26 April 2018

Accepted 29 April 2018

Keywords:

IPOs; Initial public offerings, Malaysian IPOs, Under-pricing of IPOs, Information asymmetry, Determinants of IPO under-pricing.

JEL Code: G11, G12, G14, G24, G32

\section{A B S T R A C T}

This paper examines the current status of research regarding under-pricing in the Malaysian IPOs. We have divided the review of past studies into the following categories: investor information, the choice of underwriter, ownership structure, share lock-up period, supply of IPOs, mechanism for pricing IPOs, institutional investor involvement, and board structure. We have shown that there is a noticeable decline in initial return over time, perhaps due to the strengthening of the regulatory environment and the ability of investment bankers to adequately manage the listing process of new issues. Furthermore, based on the review of past studies, we have managed to pinpoint significant factors that influenced the initial return in the Malaysian IPO market. Finally, we also provide suggestions for future research.

\section{Introduction}

To go public, a private company must first issue equity securities to outside investors, in what is called an initial public offering (IPO). Over the past three 
decades, a huge number of theoretical and empirical studies have been published on the topic of IPO initial return. Puzzling empirical findings, usually related to under-pricing of IPOs, form the main core of the growing literature on this subject. The interesting empirical findings regarding the under-pricing of IPOs have motivated researchers to develop various theoretical works that help in explaining this puzzling phenomena; many have put forth new hypotheses for the reasons for such a puzzle. Consequently, further empirical studies have also been motivated to test these new implications that have emerged from various theoretical studies.

The puzzle of IPO initial return (specifically, under-pricing of IPOs) is considered to be one of the first documented issues regarding the IPO market. Among the first empirical studies that tested under-pricing and reported a positive mean initial return (which implies the existence of under-pricing) in the U.S. IPO market, are Ibbotson (1975), Logue (1973), and Stoll and Curley (1970). Even though the puzzle refers to the under-pricing in IPOs, past studies on IPOs in the developed markets (especially the US market) also reported that the abnormal initial return (or huge under-pricing) was usually followed by subsequent negative or insignificant returns in the after-market. Yong (2013) also noticed this phenomenon of insignificant returns in the after-market with the Malaysian IPOs, namely the IPO prices stabilized in the after-market. In an informational efficient market, this under-pricing phenomenon should not take place, and that is the reason why explanations are offered to try to explain the existence of this so-called puzzle. Initial return is usually measured as the percentage change from the offer price of an IPO to the opening price (or closing price) on its first trading day, and the higher the initial return the higher is the level of under-pricing.

Ritter (1998) suggested that under-pricing depends on various aspects of the relationship between the three most important players in the IPO process, who are the investors, the issuers, and the underwriters (or the investment bankers). Ritter's argument was based on the suggestion made by Beatty and Ritter (1986) who argued that the greater the uncertainty about the value of the new issue, the greater the under-pricing needed to attract the uninformed investors. This means that the higher the information asymmetry around the new issues the higher the under-pricing would be. Both arguments, in a way, suggested that under-pricing is induced when the objectives of the underwriter, issuer and the investors are not aligned. The difference between the objectives of the underwriter, issuer and subscriber has been further explored by many researchers. Various theoretical constructs, linking the objectives of the issuer, underwriter as well as the investors have been proposed. These constructs use various existing theories collectively and individually like the information asymmetry theory, winner's curse theory, bandwagon theory, book building theory, lawsuit avoidance theory, signalling theory, underwriter reputation theory, underwriter's monopsony power theory, ownership dispersion theory, and uncertainty theory. 
The assumption of information asymmetry is the driving force behind most theoretical models, the results of which provide support for this hypothesis. Scholars have attempted to explain the initial return puzzle using the information asymmetry hypothesis. For example, Baron and Holmström (1980) documented the existence of information asymmetry between the underwriters and the issuing firms, where underwriters are better informed than the issuing firm concerning the demand for the issuing firm's securities. According to them, under-pricing is necessary in order to solve this so-called "moral hazard".

Another potential explanation for under-pricing is related to the information asymmetry between informed and uninformed investors. Rock (1986) assumed that the market could be segmented into informed and uninformed investors in which the informed have superior information regarding the firm's value over the uninformed as well as the issuing firm itself. These informed investors use their superior knowledge to participate only in under-priced issues and stay away from overpriced issues. The uninformed investors, on the other hand, randomly bid for all issues. As a result, the under-priced issues receive both informed and uninformed demand while the overpriced issues receive only uninformed demand. The uninformed investors have a lower probability of receiving underpriced issues in comparison to overpriced issues. Such confusion, according to Rock, has resulted in the winner's curse problem, causing uninformed investors to lower their valuation of IPOs and thereby reducing the uninformed demand for them. In the absence of any form of compensation, the uninformed investors would withdraw from the market due to the bias in allocation. As such, underpricing is necessary in order to attract uninformed investors to participate in the market.

In the case of the Malaysian IPOs market the level of information asymmetry is high due to the significantly weak institutional development, ${ }^{1}$ and weak investor protections, ${ }^{2}$ according to Hemmer and Bardhan (2000) and La Porta et al. (2000), respectively. Furthermore, the high level of information asymmetry may be caused by the fixed-priced offer mechanism of pricing

1 Hemmer and Bardhan (2000) argued that the low levels of institutional development in the Asian countries were caused by the following: (a) the traditional institutions of exchange in developing countries often did not evolve into more complex (impersonal, open, legal rational) rules or institutions of enforcement as in early modern Europe, (b) the institutional arrangements of a society are often the outcome of strategic distributive conflicts among different social groups, and inequality in the distribution of power and resources can sometimes block the rearrangement of these institutions in ways that are conducive to over-all development.

2 La Porta et al. (2000) defined investor protections as the ability of the legal system (both laws and their enforcement) to protect outside investors (both shareholders and creditors) from insiders. Moreover, they showed the effect of investor protections on: (a) expanding the financial markets, (b) facilitating external financing of new firms, (c) moving away from concentrated ownership and (d) improving the efficiency of investment allocation. 
IPOs, which is commonly practised in Malaysia. With the fixed-price pricing mechanism, the offer price is set by the issuing firm before the IPO is offered to the investing public (Yong 2011).

The under-pricing puzzle in IPOs has been documented in many different countries, where the literature has proven that under-pricing is not exclusive to the U.S. market alone. Various researchers in various countries have tested the under-pricing phenomenon. Many of these studies have confirmed a positive initial return in various markets around the world. This is made possible through the latest updated version (16th of February 2015) of Loughran's et al. (1994) table, which contains the average under-pricing history of 52 countries. Loughran et al. (1994), for the purpose of analysing the differences between countries and within countries, studied the average initial returns in 25 countries covering the period of 1960 to 1992 . They constructed the table by collecting figures from various studies at that time. They concluded that the degree of under-pricing varied enormously across countries due to the contractual mechanisms used and the characteristics of companies that went public. Furthermore, they argued that countries with the highest average initial returns tended to be countries where institutional constraints were binding (the average initial return at the time of the study for Jordan, Saudi Arabia, China, India and Malaysia were 149\%, 239.80\%, $118.40 \%, 88.5 \%, 56.20 \%$ respectively). Meanwhile, countries with the lowest average initial returns, i.e. below $10.0 \%$ (e.g. Canada, France, and Netherlands), tended to be countries in which most of the firms going public were relatively large firms with a long operating history and where the contractual mechanism used had auction-like features.

Despite the existence of under-pricing in many countries, the level or size of under-pricing, however, varied substantially from country to country, determined by different variables in different markets. In addition, these variables varied across time in the same market. Although the variables were not similar, three following characteristics were documented across markets:

1. The short-term under-pricing of IPOs. This is also true in the case of Malaysian IPOs. The majority of the studies in Malaysia investigated the determinants of IPO under-pricing during the short-term, usually a period represented by the first-day of return.

2. The long-term under-pricing of IPOs. This is a controversial area of discussion because there is a tendency for anomalies to disappear once they have been identified. Whether this is because the original anomaly occurred by chance during some sample period, or because the market learns and begins to price securities differently, is unclear. In Malaysia, an early study by Dawson (1987) reported a positive long-run performance (18.2\%) of Malaysian IPOs. Wu (1993) reported that, using data from the Main Board from January 1974 to December 1989, IPOs with low initial returns performed better than those with high initial returns and 
small firms tended to out-perform big firms in the long-run. Ismail et al. (1993), using data from January 1980 to December 1989, reported that returns after the initial listing of IPOs were not significant. Mohamad et al. (1994a), using data from 1975 to 1990, reported an average initial under-pricing of $135 \%$ and significant positive cumulative abnormal returns after 2 and 3 years. Yong (1996), using data from January 1990 to December 1994, reported that the benefits of under-pricing did not accrue to the secondary market traders. Nasir and Zin (1998), using the Main Board data for the period 1990-1995, reported that insignificant price fluctuation after the first-day of trading conformed to the efficient market hypothesis. Yong et al. (1999), using IPO listed on the Main Board and the Second Board between 1991 and 1995, found that average initial returns had no relation with the average annual return over the longer-term periods; the only exception was the negatively significant correlation between average initial returns and average annual returns over a three-year period.

3. The hot issue market phenomenon. In this case an IPO is impacted by the extent to which the offer has been under-priced compared to its market value; the higher the difference, the higher the subscription as investors stand to gain more in the short run. In addition, the timing of the IPO has a bearing on the outcome. For example, during the time of optimism, if IPOs flood the market every offer is likely to be oversubscribed, as the theory of animal instincts would suggest.

\section{Under-Pricing in the Malaysian IPO Market}

The literature presented in this section documents the considerable decreases in the average initial returns over time (specifically, over the years) in the Malaysian IPOs market. In the early years, Dawson (1987) reported a $166.6 \%$ abnormal average initial return in Malaysia using a sample of 21 IPOs from 1978 to 1983 , while another study by Yong (1992) documented an average initial return of $167.4 \%$. Ismail et al. (1993) reported an average initial excess return of $114.6 \%$, using a sample of 63 IPOs from 1980 to 1989. Loughran et al. (1994) reported an average initial return of $80.3 \%$ using a sample of 132 Malaysian IPOs covering the period of 1980 to 1991. Mohamad et al. (1994) examined the initial performance of 65 IPOs from the Kuala Lumpur Stock Exchange (KLSE), covering the period of 1975 to 1990, and found an average initial return of $135 \%$. Using a sample of 126 Malaysian IPOs and covering the period of 1980 to 1991, Isa and Ahmad (1996) documented an initial return of $76.8 \%$, which was considered higher than that of other markets. 
In another study covering Malaysian IPOs, Yong (1997) used a sample of 224 IPOs to examine the average initial return of the period ranging from 1990 to 1994. He reported an average initial of $72.85 \%$ offer-to-open return, an adjusted return of $72.63 \%$ offer-to-open return, an average initial of $75.03 \%$ offer-toclose return, and an adjusted return of $74.49 \%$ offer-to-close return. Jelic et al. (2001) covered a sample of 182 Malaysian IPOs from 1980 to 1995 and reported an average initial return of $99.25 \%$. Furthermore, at the same period, Yong et al. (2001) documented an average initial return of $81.6 \%$, through covering all issues in both the Main Board and the Second Board of the KLSE, from January 1991 to December 1995.

In a more recently published study, Mohd Rashid et al. (2014) focused on the issue of the lock-up period within the Malaysian IPO market and its relationship with IPO under-pricing from January 2000 to December 2012, by taking into consideration both the ratio and the duration of the lock-up. They reported an average initial return of $29 \%$, which was lower than previous reports in the literature.

Table 1 presents past studies that examined IPO initial returns in the Malaysian market. Furthermore, Figure 1 accounts for the initial return taken from various study periods. It is evident from Figure 1 that there is a noticeable decline in initial return over time, perhaps due to the strengthening of the regulatory environment and the ability of investment bankers to adequately manage the listing process of new issues. Abdul-Rahim and Yong (2008) attribute the declining trend in the initial performance of IPOs in the Malaysian market to the SC's decision to liberalise the IPO pricing mechanism in 1996 and due to the various measurements taken by the SC and the Malaysian government to counteract the adverse effects of the 1997/1998 Asian Financial Crisis. However, the average initial return in Malaysia is still high according to Figure 1. The most recently published study on initial return, by Yong (2015), reported an average initial return of around 35\% during the period 2009-2013. This finding indicates that the average initial return of the Malaysian IPO market is still quite high; perhaps due to the "still" high level of information asymmetry in the Malaysian DIPO market. 
Table 1. Summary of Past Studies on the Average Initial Return of Malaysian IPOs

\begin{tabular}{|c|c|c|c|c|}
\hline Source & Period & $\begin{array}{l}\text { Sample } \\
\text { size }\end{array}$ & $\begin{array}{c}\text { Average } \\
\text { initial return }(\%)\end{array}$ & Determinant Factors \\
\hline Dawson (1987) & $1978-1983$ & 21 & 166.70 & $*$ \\
\hline $\begin{array}{l}\text { Yong (1992) (Note: This } \\
\text { is a better version of that } \\
\text { article published in Jurnal } \\
\text { Pengurusan. } \\
\text { I attached a copy of that } \\
\text { article) }\end{array}$ & 1983-1988 & 33 & 167.40 & $*$ \\
\hline Ku Ismail et al. (1993) & 1980-1989 & 63 & 114.60 & $*$ \\
\hline Yong (1997) & 1990- 1994 & 224 & 72.85 & Over-subscription ratio \\
\hline How et al. (2007) & $1989-2000$ & 322 & 101.57 & $\begin{array}{l}\text { Regulation, multiple, uses and } \\
\text { technology }\end{array}$ \\
\hline Jelic et al. (2001) & 1980-1995 & 182 & 99.25 & $\begin{array}{l}\text { LnBV/MV (spell out in full), } \\
\text { Market, Dmultiple (spell } \\
\text { out in full) and underwriters } \\
\text { reputation }\end{array}$ \\
\hline Paudyal et al. (1998) & 1984-1995 & 98 & 61.80 & $\begin{array}{l}\text { Over-subscription ratio, } \\
\text { market volatility, underwriters } \\
\text { reputation and ex-ante risk }\end{array}$ \\
\hline Moshirian et al. (2010) & 1991-2008 & 708 & 61.81 & $*$ \\
\hline Yong and Isa (2003) & 1990-1998 & 468 & 95 & Over-subscription ratio \\
\hline $\begin{array}{l}\text { Hiau Abdullah and } \\
\text { TaufilMohd (2004) }\end{array}$ & 1991-1998 & 539 & 78.44 & $\begin{array}{l}\text { Company size, indigenous } \\
\text { population ownership and } \\
\text { substantial shareholder losses }\end{array}$ \\
\hline Wan Hussin (2005) & 1996-2000 & 154 & 83 & $\begin{array}{l}\text { Offer, demand, lock-up and } \\
\text { Dlock-up (spell out in full) }\end{array}$ \\
\hline $\begin{array}{l}\text { Abdul Rahim and Yong } \\
\text { (2008) }\end{array}$ & 1999-2007 & 386 & 31.99 & $\begin{array}{l}\text { Offer size, demand, company } \\
\text { size, offer type and season }\end{array}$ \\
\hline Low and Yong (2011) & $2000-2007$ & 368 & 30.83 & $\begin{array}{l}\text { Over-subscription ratio, offer } \\
\text { size, issue size, opportunity } \\
\text { cost of fund, IPO volume } \\
\text { dummy }\end{array}$ \\
\hline Yong (2011) & 2001-2009 & 370 & 26.34 & Private placements \\
\hline $\begin{array}{l}\text { Abdul Rahim and Yong } \\
\text { (2010) }\end{array}$ & 1999-2007 & 386 & 31.99 & Demand and offer type \\
\hline Mohd Rashid et al. (2014) & $2000-2012$ & 495 & 29 & $\begin{array}{l}\text { Lock-up period, shareholder } \\
\text { retention and potentials of } \\
\text { follow-on offerings }\end{array}$ \\
\hline Yong (2015) & 2009-2013 & 93 & 35.93 & $\begin{array}{l}\text { First-day price-spread, ratio of } \\
\text { first-day volume over total unit } \\
\text { offered, offer price, hot versus } \\
\text { cold IPOs and listing board }\end{array}$ \\
\hline
\end{tabular}

Notes. (1) The asterisk (*) indicates that the study focuses only on the initial return.

(2) The hashtag (\#) indicates that the study is based on abstracts.

Source: Published articles as compiled by the authors. 


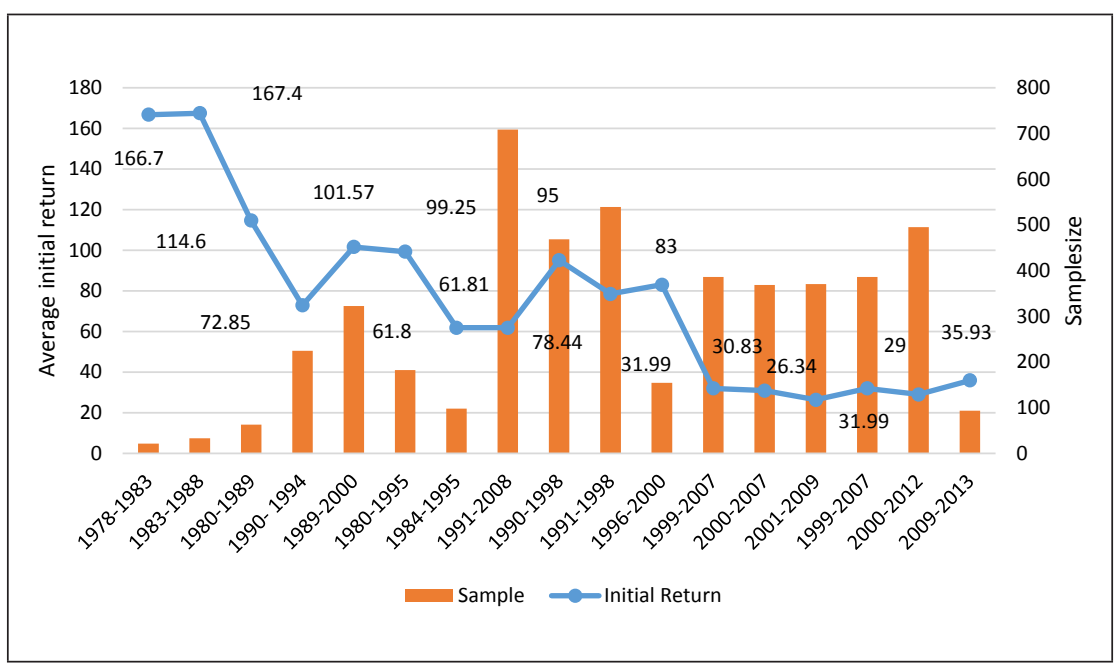

Figure 1. Average Initial Return of the Malaysian IPO Market

\section{Significant Variables in Determining Under-Pricing in Malaysia}

Various studies on Malaysian IPOs have managed to pinpoint significant factors that influence the initial return. To make the discussion more focused, in this section we divide the review of past studies into the following categories: investor Information, the choice of underwriter, ownership structure, share lockup period, supply of IPOs, mechanism for pricing IPOs, and institutional investor involvement. Paudyal et al. (1998) documented that certain variables (market volatility, over-subscription, ex-ante risk, underwriter reputation, and sector dummy) were significantly related to IPO initial excess return. Furthermore, How et al. (2007) found that users, multiple, technology, and regulation were the significant factors in explaining IPO initial return. In a more recent study, Badru and Ahmad Zaluki (2018) reported that for ex-ante variables, such as IPO risk, company size, the Altman Z-score measure of pre-IPO performance, audit quality and the technology industry, were significantly related to IPO initial returns.

\subsection{Investor Information}

In most countries, a prospectus, detailing specific and relevant information about a company, is required to be given to investors prior to the issuance of IPO. Many stock exchanges require that the company seeking listing on their stock exchange must provide certain specific information, such as the company's 
financial or accounting data for the last few years. Many of the past IPO studies attempted to find the relationship between these pieces of information and the initial return of the IPO. Variables such as firm age, profitability, number of shares to be sold, size of the firm, partial adjustment phenomenon and insider sales were the types of variables that had been studied. Many of these variables tended to be related to the level of under-pricing of IPOs. In Malaysia, an exception though, Mohamad et al. (1994b) who examined the accuracy of profit forecasts reported in the prospectuses of Malaysian IPOs found that there was no significant relationship between the forecast errors and the stock price premium (or the level of under-pricing) upon listing.

Early studies by Yong et al. (1999) and Yong and Zaidi (2003) documented that over-subscription ratio or investor demand for IPO was a variable that consistently explained the levels of initial return in Malaysian IPOs. According to Yong (2007a), investor demand is considered unique to the Malaysian IPO market due to the use of the fixed-price mechanism in setting the offer price. Under the fixed-price mechanism, information on investor demand is available to the general investing public in the form of IPO over-subscription ratio. Issuing firms rely on the over-subscription ratio to get information on IPO market demand because in the fixed price method, issuers do not have the opportunity to interact and gather information from potential investors (Low \& Yong, 2011). Furthermore, Vong (2006) argued that investor demand plays an important role in an IPO success because it reflects direct information regarding the market's reaction to the IPO. For example, a highly demanded IPO offers a better opportunity for the firm to sell shares in the future due to the reputation gained from the highly over-subscription ratio (Vong, 2006), which enhances the liquidity of the newly listed stock (Alanazi et al., 2016; Loughran and Ritter, 1995). The enhanced liquidity enables the company to raise capital on more favourable terms in the future rather than having to compensate investors for the lack of liquidity (Ritter, 1998).

In his paper, Yong (2007a) covered more variables that were available to the public before the listing date of IPOs (i.e. over-subscription ratio, number of days from last day of application of IPO to the listing day, number of days of offer period, offer size and offer price), for the study period between January 1999 and December 2003. Individually, all these variables contributed significantly to the levels of initial return, the with over-subscription ratio contributing the most. When a stepwise regression analysis was run, in general, the over-subscription ratio alone could explain much of the levels of initial return in Malaysian IPOs. Jelic et al. (2001) found that the natural logarithm of the length of operating history and the logarithm of net tangible asset per share over the first-day closing price was significantly related to the market adjusted initial return. Meanwhile, Yong and Isa (2003) showed that only the over-subscription variable contributed significantly to the IPO initial return. Wan-Hussin (2005), on the other hand, 
found that owner participation ratio was negatively associated with underpricing (or initial return) and the fractions of directors' shares that were lockedup were positively related to under-pricing. Furthermore, Wan-Hussin (2005) reported that demand (over-subscription ratio), offer size, and lock-up period were significantly related to under-pricing. Jelic et al. (2001) used market adjusted initial return as a dependent variable, and found that over-subscription ratio, the market condition of three months before issue, demand, and bookto-market value ratio were significant in explaining the market adjusted initial return. Abdul-Rahim and Yong (2010) used a sample of Malaysian IPOs and Shari>a-compliant IPOs to study under-pricing, and they found a significant relationship between the over-subscription ratio and the size of offer with the initial return. Yong (2011) found that the initial return was higher with a larger percentage of private placement IPO, in which he suggested that there was a "bandwagon effect" taking place, where uninformed investors follow the action of the informed investors when it comes to participating (or follow the bandwagon) in an IPO exercise.

\subsection{The Choice of Underwriter}

Underwriter reputation is considered to be one of the major influencing factors on the initial performance of IPOs (Kenourgios et al., 2007; Dimovski et al., 2011). The empirical evidence seems to suggest that underwriters with a better reputation tend to reduce the initial under-pricing (see, for example, Beatty and Ritter (1986), Johnson and Miller (1988), Beatty and Welch (1996), Carter et al. (1998) and Paudyal et al. (1998)). However, in the Malaysian context, very few studies have investigated the relationship between underwriter reputation and IPO initial return. Paudyal et al. (1998) documented that long-term investments were significantly better for new issuing firms with reputed underwriters than those with less reputed underwriters. Jelic et al. (2001) covered a sample of 182 Malaysian IPOs from 1980 to 1995 and reported an average initial return of $99.25 \%$. They concluded that there was no significant relationship between underwriter reputation and initial returns due to the lack of competition between underwriters. Yatim (2011) reported a positive relationship between the reputation of investment banks and under-pricing. Her study covered 385 IPOs from October 1999 to February 2008.

Tong and Ahmad (2015) reported a negative relationship between underwriter reputation (Big 5 underwriters) and under-pricing, which means that the higher the reputation of an underwriter, the lower the level of underpricing. Their study covered 322 IPOs, from January 2002 to December 2008. However, Ammer and Ahmad-Zaluki (2016) found that IPOs underwritten by the Big 5 underwriters that had high market share and charged low underwriting spread experienced higher levels of under-pricing. Furthermore, they reported 
that under-pricing increased with IPOs with biased earnings forecasts. Finally, they revealed that the more accurate the earnings forecasts were, the more minimised would the asymmetric information be and hence, the less would the IPO under-pricing be. Previous studies have investigated the relationship between underwriter reputation and under-pricing. However, the empirical findings were mixed. Underwriter reputation was reported to have a positive (Dimovski \& Brooks 2008; Kenourgios et al., 2007) and negative (Jelic et al., 2001; Neuberger \& Chapelle, 1983) relationship with initial return. Beatty and Welch (1996) showed that the relationship between IPO under-pricing and underwriter reputation had shifted from a negative to a positive one. They explained this change was a result of the aspect of different economic conditions during different periods.

\subsection{Ownership Structure}

With an IPO, the ownership structure will change and the shares sold in the IPO are designated as Primary shares (or Public Issue in the context of Malaysian IPOs), which are new shares, and Secondary shares (or Offer for Sale as it is known in Malaysia), which are shares that were previously owned by existing shareholders, usually founders and managers of the firm. The size of the new issue relative to the existing shares and their distribution will change the ownership structure. Ritter (1998) reported that most of the firms that were going public would offer around $20 \%-40 \%$ of their shares to the public, while the preIPO shareholders would retain the rest of the shares. Going for IPO is considered a critical phase in separating ownership and firm control.

The availability of some unique features in the Malaysian IPO market caused it to be different from other markets in the world. One of those unique features was caused by the New Economic Policy instrument that was introduced by the Malaysian government in the 1970s. The main objective of such a policy was to improve Malaysian (Bumiputera) investor's participation and ownership in the equity market. To implement this objective, starting from 1976, each company that seeks listing on the Kuala Lumpur Stock Exchange (KLSE) must allocate $30 \%$ of its total issued shares to Bumiputera and that can be done directly or through Bumiputera institutions (institutions catering for Malays only) such as unit trusts launched by the National Equity Corporation (Permodan Nasional Berhad). On the $1^{\text {st }}$ of November 2012 under the "Bumiputera Equity Requirements For Public Listed Companies", the Securities Commission (SC) announced that corporations seeking a listing on the Main Market must allocate at least $12.5 \%$ of their enlarged issued and paid-up share capital to Bumiputera investors.

Saadouni et al. (2005), using 322 IPOs listed on the Second Board for the period 1989-2000, found that under-pricing was inversely related to the 
proportion of shares allocated to Bumiputera investors. On average, Bumiputera investors and the Malaysian public are allocated almost an equal proportion and make similar profits per issue. However, institutional Bumiputera investors appear to be allocated a higher proportion of the over-priced issues than the most under-priced ones. How et al. (2007) analysed share allocations in the Malaysian Second Board IPOs market, covering 322 IPOs from 1989 to 2000. They found that Bumiputera investors and the Malaysian public received almost an equal allocation and made similar profits per issue. Furthermore, they documented that IPOs with a higher share allocation to retail Bumiputera investors performed better in both the short and long run.

\subsection{Share Lock-Up Period}

Lock-up period refers to a period where insiders are prohibited from selling shares without the written permission of the lead underwriter. In the US, the average period is 180 days or 6 months. The lock-up provision is an attempt to control the supply of shares sold during the period after the IPO by the insiders or the existing shareholders. Mohan and Chen (2001) and Brav and Gompers (2003) argued that the structure of the lock-up agreements reflects the degree of the adverse selection or moral hazard problem, and thus resulting in IPOs being under-priced. In Malaysia, share lock-up is commonly known as share moratorium. The lock-up (share moratorium) agreement was made mandatory for particular new issuers in the Malaysian IPO market starting from May 3, 1999. In the following years, the IPO agreement went through several amendments, with significant changes in the lock-up agreement occurring in 2003, 2008, and 2009. The revisions of 2009 were the most restrictive and vigilant on lock-up agreement, in which most of these changes were made to protect investors' interests. This enforcement of the lock-up agreement differentiates the Malaysian IPO market from the rest of the world, especially the U.S. and the U.K. IPO markets. In developed countries the implementation of the lock-up agreement is built on a voluntary basis that depends on the outcomes of the negotiations between the insiders of the IPO company and the investment bank. According to Wan-Hussin (2005), there had not been enough empirical attention on the lockup period in Malaysia, even though there was a huge emphasis on the lock-up period by the Malaysian SC.

Mohan and Chen (2002) and Wan-Hussin (2005) were among the early studies that discussed the relationship between lock-up period and initial return in Malaysia. Both studies came to the same agreement in the case of Malaysia, namely specific companies or industries characterised with relatively higher risk than the traditional norm in the market were imposed with a lock-up period to protect the investors. They also concluded that both higher lock-up ratios and a longer lock-up period were signals for increased risk, which resulted in higher 
initial return. During the period of his study, Wan Hussin stated that major shareholders were not allowed to sell 45 percent of IPOs within one year, and in every subsequent year, they were allowed to dispose one third of the shares that were under the moratorium. Mohd Rashid et al. (2014) reported in their study that based on the risk-signalling hypothesis it could be concluded that both the lock-up ratio and lock-up period had positives relationship with the initial return in the Malaysian IPOs market. In their study, they showed that the effect of the lock-up period was more pronounced than the effect of the lock-up ratio, which they considered to be preliminary. They documented that both the lock-up period and the lock-up ratio were more appropriate for signalling the quality Dof the issuing firm than the risk of the issuing firm. Furthermore, they concluded that the relationship with the initial return was more pronounced in the case of lock-up periods rather than lock-up ratios, and lock-up periods were more appropriate for signalling the quality of the firm.

Recent studies regarding the lock-period are more interested in investigating the effect of the lock-up provisions on trading volume changes around the lock-up expiry date (Zameni \& Yong 2016) and on trading volume changes around the lock-up expiry date (Zameni \& Yong 2016). Zameni and Yong (2016) reported a positive abnormal trading volume at the lock-up expiry date for IPO market, except for the ACE market, the construction sector and the technology sector, where it was negative. They argued that the high trading volume at and around the lock-up expiration is compatible with shareholders' selling due to diversification reasons and wealth recognition and which is also an indication of insiders' lack of confidence about a company's future prospects. Furthermore, the significant negative trading volume can be interpreted in a way that insiders of those related boards and sectors do not sell their shares significantly but would rather watch what would happen to the market and are optimistic about the market's future. Zameni and Yong (2017) documented that the share price drop around the lock-up expiry was due to the increase in the adverse selection element of the bid-ask spread, which resulted from the trading volume increase around the lock-up expiry.

Supply of IPOs:

Supply of IPOs is built on the assumption that investors do not consider the IPOs of all firms as equally the same; by doing so, they discriminate IPOs based on a firm's characteristics, thus lowering the IPO initial return as the supply of IPOs increase. The offer size (OFFSZ) is used to measure the IPO supply, which is represented as

$$
O F F S Z=\operatorname{In}\left(N O S H I x P^{\text {OFFER }}\right)
$$


where, $\ln =$ natural logarithm, NOSHI = total number of shares issued, and $P^{O F F E R}=$ offer price.

Yong (2007a) used offer size as a variable to explain the level of underpricing in the Malaysian IPOs, and concluded that it was quite significant in explaining the under-pricing level. The Malaysian literature has reported a negative relationship between the supply of IPOs and initial return, which means the smaller the supply, the higher the level of under-pricing. This negative correlation is fuelled by the smaller supply of shares that leads to greater pressure on initial return (Abdul-Rahim \& Yong, 2010; Yong, 2007a, Yong., 2009, Mohd Rashid et al., 2014). Abdul-Rahim and Che-Embi (2013) used a sample of 384 IPOs from January 1999 to December 2008 to investigate the different factors that influence the initial returns of Shariah versus non-Shariah IPOs. They found that the unlike the initial returns of the non-Shariah IPOs, the initial returns of the Shariah IPOs were also explained by the offer size.

\subsection{Mechanism for Pricing IPOs}

Three mechanisms are used in IPOs around the world, namely auctions, fixedpriced offers, and book building. In auctions the market-clearing price is determined after bids are submitted. In a fixed-price offer, the price is set prior to the allocation. If there is excess demand, shares are rationed on a pro rata or lottery basis. In book building, the underwriter solicits the opinion of the potential investors regarding the offer price through their bids and then Dsets an offer price.

The most common mechanism by which IPOs are sold around the world is building. Auctioned IPOs in France, Israel, Japan, Taiwan and the US are associated with low but positive initial returns, compared with fixed-price offers and book building IPO sale regimes. In Malaysia the fixed-priced mechanism is the most popular practice when it comes to pricing an offer price (Low \& Yong, 2013; Yong, 2015). In a fixed-price method, the offer price of the issue is set prior to the listing by the issuing firm. However, the settled price does not reflect the true value of the listing firm's issues because prospective investors are not given the opportunity to reflect their expectations and beliefs regarding the offer price of the IPO, unlike the book building and auction methods that allow investors to be solicited by the issuers regarding the value of the IPO before the offer price is set. Not factoring the prospective investors in the offer price will lead to heterogeneity of opinion among investors (Yong, 2015; Chowdhry \& Sherman, 1996). This heterogeneity is the repercussion of the divergent prior expectations the prospective investors have regarding the true value of the listing firm. This heterogeneity has important behavioural implications (Miller, 1977; Goldberg \& Nitzsch, 2001), where investors' interpret the information as they 
see fit. This will likely affect their willingness to buy or sell the IPO, and the overall investors' decisions are reflected in the range of trading prices, as shown by the first-day price spread (Yong, 2015; Low \& Yong, 2013), which lead to increase in the under-pricing.

Yong (2015) and Low and Yong (2013) documented a significant relationship between under-pricing and first-day price spread. They argued that the higher the under-pricing the higher the heterogeneous beliefs among investors. Yong (2015) investigated the relationship between investor heterogeneity and initial return, ratio of first-day volume over total units offered, and listing board. He concluded that IPOs that were characterised with high initial return, high first-day trading volume, and listed on the ACE Market suffered from very high divergence of opinions regarding their true values among the investors due to their speculative nature. Moreover, Low and Yong (2013) documented IPOs that were highly under-priced, small in offer size and were listed on the MESDAQ Market tended to have a high level of heterogeneous beliefs among investors.

\subsection{Institutional Investor Involvement}

In the context of the institutional investors versus retail investors, in Malaysia, IPOs are categorised into two main groups, namely the private placement and the non-private placement. With private placement, IPOs are offered directly to the institutional investors, who are considered in the finance literature as informed investors. Non-private placement IPOs are offered to retail investors, who on the other hand, are considered to be the so-called uninformed investors. The winner's curse hypothesis suggested by Rock (1986) posits that IPOs involving more institutional investors are seen to be less risky investments and accordingly require lower initial return. The results of a study by Yong (2011) indicated that, probably due to fear of being trapped in the winner's curse situation, the lack of informed institutional investors in an IPO exercise was compensated with higher initial returns (or higher level of under-pricing). Yong (2011) used 370 IPOs covering the period from January 2001 to December 2009 to investigate the issues of winner's curse and bandwagon effect in explaining the under-pricing phenomenon of Malaysian IPOs. He concluded that the average initial return for the Malaysian private placement IPOs (a proxy for informed investors) was significantly lower than that of the non-private placement IPOs (a proxy for uninformed investors), which gives support to the winner's curse hypothesis, where uninformed investors demand a higher initial return in the absence of informed investors. This finding is further supported by Mohd Rashid et al. (2014) who concluded that institutional investor participation had a significantly negative coefficient, indicating that uninformed investors (nonprivate placement subscribers) tended to demand higher initial returns compared to informed investors (private placement subscribers). Finally, on the issue of 
IPO flipping (the immediate selling of an IPO by the successful subscribers upon IPO listing in the open market), Che-Yahya et al. (2014) examined the influence of institutional investors' participation in the flipping activity of Malaysian IPOs. They concluded that greater participation of institutional investors during an IPO is expected to be an effective strategy to control aggressive flipping activity; this means that greater participation of institutional investors during an IPO is expected to be an effective strategy to control aggressive flipping activity.

\subsection{Board Structure}

The purpose and effectiveness of the board of directors have been described by various theories in multiple disciplines. A few of these theories which have dominated board research are the stewardship theory (Donaldson \& Davis, 1991, 1994), institutional theory (Meyer \& Rowan, 1977), agency theory (Jensen \& Meckling, 1976), social network theory (Burt, 1992) and resource dependence theory (Pfeffer \& Salancik, 2003). These theories may seem random and different, but all of them agree on one thing, namely firm outcomes (performance) are affected by the concrete actions and activities performed by the boards. Certo (2003) extended the literature by showing that board characteristics have a symbolic role that is independent of the board's tangible activities and have the ability to influence the performance of the issuing firms in the contexts of IPOs. Certo (2003) concluded that board structure features represent significant nonfinancial information that IPO investors should take into consideration when making investment decisions. In this review paper, we only focused on two board structure features, namely the board reputation and the board size.

In the case of Malaysia, Yatim (2011) examined the relationship between board structure and initial return using 385 IPOs from 1999 to 2008. In her study, she looked at four board structure variables, which were board independence, dual leadership structure, board reputation, and board size. She concluded that due to the risky nature of IPO firms, Malaysian investors did not favour the separation of board chair and CEO positions, instead preferred stability and continuity in executive leadership. This resulted in a positive and significant relationship between board reputation, and initial returns. However, Yatim (2011) reported a negative correlation between board reputation and the initial return. Finally, both board size and board independence were not significantly correlated with the initial returns. In a more recent study, Badru et al. (2017) examined the impact of board characteristics on the amount of capital raised through an IPO from a sample of 220 Malaysian IPOs over the period of 2005 to 2015. Using the OLS regression, they reported that boards with ethnic Malay directors had a significant and positive association with the amount of capital raised, while a weak significance was found for board size. However, using 
the robust regression techniques, they managed to document that other than board ethnicity, other board characteristics, namely board size, board independence and CEO duality were significantly associated with the amount of capital raised

\section{Suggestions for Future Research}

Throughout this paper we have managed to identify several areas that future research can cover to bring the Malaysian literature closer to understanding what causes under-pricing and how it can be minimised. In fact, many of the studies conducted in the developed markets can be further examined in the context of a developing market like Malaysia. For starters, future research can examine the regulatory environment (Yong, 2007b) such as the listing requirements for IPOs (Moshirian et al., 2010; Jelic et al., 2001), and legal investors' protection (Liu et al., 2014; Espenlaub et al., 2016), and how these issues influence the underpricing levels of Malaysian IPOs.

As suggested by Yong (2007b), in the context of Asian IPOs, future research should also look at the influence of the differences in Malaysian laws (related to the issuance of IPOs or IPO in general) and their enforcement, on the level of under-pricing. A few studies touched on these issues, such as Banerjee et al. (2011) and Espenlaub et al. (2016), however, these studies investigated Malaysia as a part of a cross-country study. There are a few studies that focused entirely on those issues in the Malaysian IPO market, such as Saadouni et al. (2005) who reported that the change in regulation to in a market-based pricing mechanism in 1996 had an "adverse effect" on under-pricing, namely IPOs listed before the change in regulatory environment were significantly less under-priced than those listed after the change.

Malaysia is one of the leading countries when it comes to Islamic finance. However, only a few studies, such as that of Abdul-Rahim and Yong (2008), Abdul-Rahim and Yong (2010) and Abdul-Rahim and Che-Embi (2013) attempted to examine the influence of the Sharia-compliant status on the IPO under-pricing. Future research should identify more predictive variables that may explain the initial returns (or under-pricing) in the Malaysian IPO market with a focus on the implications of the Sharia-compliant status.

Finally, the marketing of IPOs is another area of research that needs serious attention from researchers in Malaysia. Regarding this issue, research can be conducted on the issue related to under-pricing of IPOs as a "marketing tool" to promote the new listing of a company. This issue was raised by Yong (2007b), but, to date, no research has been conducted on this issue in the Malaysian IPO market. 


\section{Concluding Remarks}

This paper aimed to review the issues surrounding the under-pricing of the Malaysian IPOs. We put forth the idea that information asymmetry was the main cause of under-pricing in the Malaysian IPO market. We also proposed that the information symmetry was caused by the use of fixed-price mechanism in pricing the IPOs as well as the weak institutional development, and weak investor protection. These factors caused a miscommunication among the three most important players in the IPO process; the investors, the issuers and the underwriters. According to Ritter (1998) this information asymmetry is the main cause of under-pricing. However, the level of information asymmetry in the Malaysian IPO market has reduced dramatically through the last decade as shown in Figure 1. This reduction was perhaps due to the SC's decision to liberalise the IPO pricing mechanism in 1996 and due to the various measurements taken by the SC and the Malaysian government to counteract the adverse effect of the 1997/1998 Asian Financial Crisis. The Asian Financial Crisis helped the Malaysian capital market to develop a better regulatory framework and a stronger infrastructure. Malaysia was able to do so through several initiatives to facilitate the recovery process. For example, to mitigate the financial crisis, the SC introduced the Malaysian Code on Corporate Governance (MCCG) in 2000 (latest revision 2007). For strengthening the standards of investor protection, the SC issued the Capital Market Master Plan (CMP) in 2001, which focuses on enhancing disclosure and governance standards. The Malaysian government introduced the Third Outline Perspective Plan 2001-2010 (OPP3) in April 2001, which promotes the idea of leapfrogging to a knowledge economy. Finally, Malaysia's Capital Market Master Plan was drafted to guide the development of Malaysia's capital markets during the decade 2001-2010. The CMP laid out a structured and comprehensive reform plan that sought to establish new markets, asset classes and intermediaries, and to strengthen existing ones. The CMP was developed with a view toward establishing domestic capital markets that would be internationally competitive and meet the needs of domestic issuers and investors and facilitate long-term economic growth in line with Malaysia's national development plans.

In this paper, based on the review of past studies, we managed to pinpoint significant factors that influenced the initial return in the Malaysian IPO market. In order to make the discussion more focused, we divided the review of the past studies into the following categories: investor Information, choice of underwriter, ownership structure, share lock-up period, supply of IPOs, mechanism for pricing IPOs, institutional investor involvement, and board structure. The review of past studies indicated that under-pricing is still a phenomenon that lingers in the Malaysian IPO market, but not as high as it used to be. Different studies have 
used different methods to identify the determinants of under-pricing, however, a definitive explanation of the IPO under-pricing anomaly remains a source of debate, specifically in the context of Malaysian IPOs, and research in IPOs in general. The reasons for this inconsistency in the results are due to factors such as the sample size used, selection of the IPO market, sample period, measurements of the study variables and models used by the researchers. As a result, the IPO literature has yet to come to a conclusion regarding the principle theoretical reason for under-pricing, and only a few studies really explain the importance of the different views regarding under-pricing (Ritter \& Welch 2002).

We end this paper by providing some suggestions regarding possible future research on Malaysian IPOs. We, however, do not claim that the list is complete. In fact, any research on IPOs conducted in the developed markets can be carried out here provided the data are available and the storyline is worth pursuing.

\section{References}

Abdul-Rahim, R., \& Che-Embi, N. C. E. (2013). Initial returns of Shariah versus non-Shariah IPOs: Are there any differences? Jurnal Pengurusan, 39(1), $1-14$.

Abdul-Rahim, R., \& Yong, O. (2008). Initial returns of Shariah-compliant IPOs in Malaysia. Capital Market Review, 16(2), 270-279.

Abdul-Rahim, R., \& Yong, O. (2010). Initial returns of Malaysian IPOs and Shari'a compliant status. Journal of Islamic Accounting and Business Research, 1(1), 60-74.

Alanazi, A. S., Liu, B., \& Al-Zoubi, H. A. (2016). IPO underpricing in supply and demand framework: Evidence from a market of retailers. Applied Economics, 48(60), 5835-5849.

Ammer, M. A., \& Ahmad-Zaluki, N. A. (2016). The effect of underwriter s market share, spread and management earnings forecasts bias and accuracy on underpricing of Malaysian IPOs. International Journal of Managerial Finance, 12(3), 351-371.

Badru, B. O., \& Ahmad Zaluki N. A. (2018). Explaining IPO initial returns in Malaysia: Ex-ante uncertainty versus signalling. Asian Review of Accounting, 26(1), 84-106.

Badru, B. O., Ahmad-Zaluki, N. A., \& Wan-Hussin, W. N. (2017). Board characteristics and the amount of capital raised in the Malaysian IPO market. Journal of Multinational Financial Management, 42-43, 37-55.

Banerjee, S., Dai, L., \& Shrestha, K. (2011). Cross-country IPOs: What explains differences in under-pricing? Journal of Corporate Finance, 17, 12891305. 
Baron, D.P., \& Holmström, B. (1980). The investment banking contract for new issues under asymmetric information: Delegation and the incentive problem. Journal of Finance, 35(5), 1115-1138.

Beatty, R.P., \& Ritter, J.R. (1986). Investment banking, reputation, and the under-pricing of initial public offerings. Journal of Financial Economics, 15(1-2), 213-232.

Beatty, R.P., \& Welch, I. (1996). Issuer expenses and legal liability in initial public offerings. Journal of Law and Economics, 39(2), 545-602.

Brav, A., \& Gompers, P.A. (2003). The role of lock-ups in initial public offerings. Review of Financial Studies, 16(1), 1-29.

Burt, R.S. (1992). Structural holes: The social structure of competition. Cambridge: Harvard University Press.

Carter, R. B., Dark, F. H., \& Singh, A. K. (1998). Underwriter reputation, initial returns, and the long-run performance of IPO stocks. Journal of Finance, 53(1), 285-311.

Certo, S.T. (2003). Influencing initial public offering investors with prestige: Signalling with board structures. Academy of Management Review, 28 (3), 432-446.

Che-Yahya, N., Abdul-Rahim, R., \& Yong, O. (2014). Moderating effect of investor demand on the relationship between institutional investors' participation and flipping activity. Labuan Bulletin of International Business \& Finance, 12, 1-12.

Chowdhry, B., \& Sherman, A. (1996). International differences in oversubscription and under-pricing of IPOs. Journal of Corporate Finance, 2, 359-381.

Dawson, M.S. (1987). Secondary stock market performance of initial public offers, Hong Kong, Singapore and Malaysia: 1978-1984. Journal of Business Finance and Accounting, 14(1), 65-76.

Dimovski, W., \& Brooks, R. (2008). The under-pricing of gold mining initial public offerings. Research in International Business and Finance, 22(1), $1-16$.

Dimovski, W., Philavanh, S., \& Brooks, R. (2011). Underwriter reputation and underpricing: Evidence from the Australian IPO market. Review of Quantitative Finance and Accounting, 37(4), 409-426.

Donaldson, L., \& Davis, J. H. (1991). Stewardship theory or agency theory: CEO governance and shareholder returns. Australian Journal of Management, 16, 49-66.

Donaldson, L., \& Davis, J. H. (1994). Boards and company performanceresearch challenges the conventional wisdom. Corporate Governance, An International Review, 2(3), 151-160.

Espenlaub, S., Goyal, A., \& Mohamed, A. (2016). Impact of legal institutions on IPO survival: A global perspective. Journal of Financial Stability, 25, 98-112. 
Golberg, J., \& Nitzsch, R. (2001). Behavioural finance. London: John Wiley and Sons, Inc.

Hemmer, H., \& Bardhan, P. (2000). Understanding under-development: Challenges for institutional economics from the point of view of poor countries. Journal of Institutional and Theoretical Economics-Zeitschrift Fur Die Gesamte Staatswissenschaft, 156(1), 216-235.

Hiau-Abdullah, N., \& Mohd-Taufil, K. (2004). Factors influencing the underpricing of initial public offerings in an emerging market: Malaysian evidence. IIUM Journal of Economics and Management, 12(2), 193-212.

How, J., Jelic, R., Saadouni, B., \& Verhoeven, P. (2007). Share allocations and performance of KLSE second board IPOs. Pacific-Basin Finance Journal, 15(3), 292-314.

Ibbotson, R.G. (1975). Price performance of common stock new issues. Journal of Financial Economics, 2(3), 235-272.

Isa, M., \& Ahmad, R. (1996). Performance of new issues on the Malaysia stock market. Malaysia Journal of Economic Studies, 13(2), 53-66.

Ismail, K. N. I. K., Abidin, F. Z., \& Zainuddin, N. (1993). Performance of new stock issues on the KLSE. Capital Market Review, 1(1), 81-95.

Jelic, R., Saadouni, B., \& Briston, R. (2001). Performance of Malaysian IPOs: Underwriters reputation and management earnings forecasts. PacificBasin Finance Journal, 9(5), 457-486.

Jensen, M., \& Meckling, W. (1976). Theory of the firm: Managerial behaviour, agency costs and ownership structure. Journal of Financial Economics, 3(4), 305-360.

Johnson, J., \& Miller, R. (1988), Investment banker prestige and the underpricing of initial public offerings. Financial Management, 17, 17-29.

Kenourgios, D. F., Papathanasiou, S., \& Melas, E. R. (2007). Initial performance of Greek IPOs, underwriter's reputation and oversubscription. Managerial Finance, 33(5), 332-343.

La Porta, R., Lopez-de, S. F., Shleifer, A., \& Vishny, R. (2000). Investor protection and corporate governance. Journal of Financial Economics, 58(1-2), 3-27.

Liu, J., Uchida, K., \& Gao, R. (2014). Legal protection and under-pricing of IPOs: Evidence from China. Pacific-Basin Finance Journal, 27, 163-187.

Logue, D. E. (1973). On the pricing of unseasoned equity issues: 1965-1969. Journal of Financial and Quantitative Analysis, 8(1), 91-103.

Loughran, T., \& Ritter, J. R. (1995), The new issues puzzle. Journal of Finance, 50, 23-51.

Loughran, T., Ritter, J. R., \& Rydqvist, K. (1994). Initial public offerings: International insights. Pacific-Basin Finance Journal, 3(1), 139-140.

Low, S. W., \& Yong, O. (2011). Explaining over-subscription in fixed-price IPOs: Evidence from the Malaysian stock market. Emerging Markets Review, 12(3), 205-216. 
Low, S-W., \& Yong, O. (2013). Initial public offerings and investor heterogeneity: Evidence from Malaysia. American Journal of Finance and Accounting, 3(1), 41-56.

Meyer, J. W., \& Rowan, B. (1977). Institutionalized organizations: Formal structure as myth and ceremony. American Journal of Sociology, 83(2), 340-363.

Miller, E. (1977). Risk, uncertainty and divergence of opinion. Journal of Finance, 32, 11511168.

Mohamad, S., Nassir, A. M., \& Ariff, M. (1994a). Analysis of under-pricing in the Malaysian new issue market during 1975-1990: Are new issues excessively priced? Capital Markets Review, 2(2), 17-28.

Mohamad, S., Nassir, A. M., Kuing, T. K., \& Ariff, M. (1994b). The accuracy of profit forecasts of Malaysian IPOs. Capital Markets Review 2(2), 49-69.

Mohan, N., \& Chen, C. (2002). Information content of lock-up provisions in initial public offerings. International Review of Economics and Finance, 10(1), 41-59.

Mohd Rashid, R., Abdul-Rahim, R., \& Yong, O. (2014). The influence of lockup provisions on IPO initial returns: Evidence from an emerging market. Economic Systems, 38(4), 487-501.

Moshirian, F., Ng, D., \& Wu, E. (2010). Model specification and IPO performance: New insights from Asia. Research in International Business and Finance, 24(1), 62- 74.

Nasir, N. M., \& Zin, R. M. (1998). The examination of the under-pricing of initial public offerings (IPOs) in Malaysia: 1990-1995. Capital Markets Review, 6(1\&2), 55-68.

Neuberger, B. M., \& Chapelle, C. A. L. (1983). Unseasoned new issue price performance on three tiers: 1975-1980. Financial Management, 12(3), 23-28.

Paudyal, K., Saadouni, B., \& Briston, R. (1998). Privatisation initial public offerings in Malaysia: Initial premium and long-term performance. Pacific-Basin Finance Journal, 6(5), 427-451.

Pfeffer, J., \& Salancik, R. G. (2003). The external control of organizations a resource dependence perspective. (2nd ed). Stanford, California: Stanford University Press.

Ritter, J. R., \& Welch, I. (2002). A review of IPO activity, pricing, and allocations. Journal of Finance, 57(4), 1795-1828.

Ritter, J. R. (1998). Initial public offerings. Contemporary Finance Digest, 2(1), 5-30.

Rock, K. (1986). Why new issues are under-priced. Journal of Financial Economics, 15(1-2), 187-212.

Saadouni, B., J. How, \& R. Jelic. (2005). Share allocation and the performance of the KLSE Second Board IPOs. Paper presented at the AFA 2005 Conference, Kuala Lumpur, Malaysia, July 11-13. 
Stoll, H. R., \& Curley, A. J. (1970). Small business and the new issues market for equities. Journal of Financial and Quantitative Analysis, 5(3), 309-322.

Tong L. Y., \& Ahmad, R. (2015). The signalling power of the investment banks' reputation on the performance of IPOs on Bursa Malaysia. Jurnal Pengurusan, 45(1), 1-16.

Vong, A. P. (2006). Rate of subscription and after-market volatility in Hong Kong IPOs. Applied Financial Economics, 16(1), 1217-1224.

Wan-Hussin, W. N. (2005). The effects of owners' participation and lock-up on IPO underpricing in Malaysia. Asian Academy of Management Journal, 10(1), 19-36.

Wu, T. S. (1993). The long-run performance of initial public offerings in Malaysia. Capital Markets Review, 1, 61-80.

Yatim, P. (2011). Under-pricing and board structures: An investigation of Malaysian initial public offerings (IPOs). Asian Academy of Management Journal of Accounting and Finance, 7(1), 73-93.

Yong, O. \& Isa, Z. (2003). Initial performance of new issues of shares in Malaysia. Applied Economics, 35(8), 919-930.

Yong, O. (1992). Behaviour and performance of new issues in Malaysia. Jurnal Pengurusan, 11, 53-61.

Yong, O. (1996). Who actually did gain from the under-pricing of IPOs. Capital Markets Review, 4(1), 33-47.

Yong, O. (1997). Initial public offerings: The Malaysian experience 1990-1994. In Bos, T. \& Fetherston, T.A. (Eds.), Advances in Pacific-Basin Capital Markets, 3, 177-188. Greenwich, Connecticut: JAI Press Inc.

Yong, O. (2007a). Investor demand, size effect and performance of Malaysian initial public offerings: Evidence from post-1997 financial crisis. Jurnal Pengurusan, 26, 25-47.

Yong, O. (2007b). A review of IPO research in Asia: What's next? PacificBasin Finance Journal, 15, 253-275.

Yong, O. (2009). Significance of investor demand, firm size, offer type and offer size on the initial premium, first-day price spread and flipping activity of Malaysian IPOs. Prosiding Persidangan Kebangsaan Ekonomi Malaysia (PERKEM), 18(1-2), 387-404.

Yong, O. (2011). Winner's curse and bandwagon effect in Malaysian IPOs: Evidence from 2001-2009. Jurnal Pengurusan, 32(1), 21-26.

Yong, O. (2013). When do after-market IPO prices stabilize? Evidence from Malaysian fixed-price IPOs. International Review of Business Research Papers, 9(4), 77-90.

Yong, O. (2015). What is the "true" value of an initial public offering? Journal of Scientific Research and Development, 2(10), 78-85.

Yong, O., Yatim, P., \& Sapian, R. Z. (1999). Significance of board of listing and type of issue on the under-pricing and after-market performance of Malaysian IPOs. Capital Markets Review, 7(1 \& 2), 47-74. 
Yong, O., Yatim, P., \& Sapian, R. Z. (2001), Initial and long-run performance of new issues on the Malaysian stock market. Corporate Finance Review, 5(6), 28-41.

Zameni, A., \& Yong, O. (2016). Lock-up expiry and trading volume behaviour of Malaysian initial public offering's. International Journal of Economics and Financial Issues, 6(S3), 12-21.

Zameni, A., \& Yong, O. (2017). Effects of lock-up expiry on bid-ask spread of Malaysian IPOs. American J. Finance and Accounting, 5(1), 64-84. 